\title{
Analysis of Shoreline Change along Cape Coast-Sekondi Coast, Ghana
}

\author{
Ishmael Yaw Dadson, ${ }^{1}$ Alex Barimah Owusu, ${ }^{2}$ and Osman Adams ${ }^{3}$ \\ ${ }^{1}$ Department of Geography Education, University of Education, Winneba, Ghana \\ ${ }^{2}$ Department of Geography and Resource Development, University of Ghana, Legon, Ghana \\ ${ }^{3}$ Department of Geography and Regional Planning, University of Cape Coast, Cape Coast, Ghana
}

Correspondence should be addressed to Alex Barimah Owusu; owusuba@yahoo.com

Received 8 December 2015; Revised 5 April 2016; Accepted 24 April 2016

Academic Editor: Eva Papastergiadou

Copyright (C) 2016 Ishmael Yaw Dadson et al. This is an open access article distributed under the Creative Commons Attribution License, which permits unrestricted use, distribution, and reproduction in any medium, provided the original work is properly cited.

\begin{abstract}
The two most important factors constantly impinging on the net movement of shorelines are erosion and accretion. This study analyzed the role of erosion and accretion in shoreline changes along the coast between Cape Coast and Sekondi in the central and western regions of Ghana, respectively. Aerial photographs, satellite images, and topographical maps were used. In addition, field survey using Global Positioning System (GPS) was conducted at selected locations due to the unavailability of satellite image for 2013. Shoreline change analysis was conducted using Digital Shoreline Analysis Systems based on End Point Rate formula. In addition, community interactions were also conducted to get first-hand information from the local inhabitants. The study finds that the shoreline under study has been fluctuating. The sea advanced inland between 1972 and 2005, which is attributed mainly to intense erosion. The study further reveals that, in the past five years, the shoreline had been retreating mainly due to increased accretion. It is recommended that the shoreline under study should be monitored regularly to keep abreast with net movements that will occur in either the short term or the long term so as to factor the net effect into the management of the coastal zone.
\end{abstract}

\section{Introduction}

The coast has long been an area that has provided communities with a multitude of benefits: food, clean water, jobs, recreation, and protection from hurricanes. Coasts provide natural harbours for commerce, trade, and transportation; beaches and shorelines that attract residents and tourists; and wetlands and estuaries that are critical for sustained fisheries. Coastal ecological systems help to mitigate floods and serve as buffers from coastal storms that bring high winds and salt water inland and erode the shoreline. Coastal regions have also been critical in meeting the developmental needs of coastal communities, including transportation, and processing of oil and natural gas resources.

Coastal communities worldwide are becoming increasingly vulnerable to a wide range of potential hazards including shoreline erosion, coastal inundation, and coastal resource degradation. In Ghana, many of the problems relate to shoreline erosion and accretion and they are currently being exacerbated by climate change, rapid urbanization, and the concomitant anthropogenic beach changes which influence other coastal processes $[1,2]$. The shoreline of Ghana is approximately $550 \mathrm{~km}$ long. It is generally described as low lying and below the $30 \mathrm{~m}$ contour above sea level, thus making it prone to erosion [1]. The shoreline of Ghana, like the rest of the world, has changed over the years in response to changes in the natural environment. Such changes have occurred over a wide range of spatial and temporal scales that reflect influences such as movement of the Earth crust, coastal engineering, variations in sea level, changes in climate, and human activities $[1,2]$. The ways in which these factors have influenced shoreline changes are well documented and presented as follows.

Shoreline Change due to Earth Crust Movement. The different ways in which movement of Earth crust caused shoreline changes are described by Waugh [3] as terrestrial factors. They include tectonics (plate movement and volcanism), 
geology (rock type and structure), weathering, deposition, and biotic factors. These processes are known to either remove or deposit materials which have altered the nature, location, and temporal dynamics of the shoreline.

The second factor known to have contributed to the shoreline change is the variations in sea level. The mean sea level is not a static point with the same elevation everywhere but currents and variations in the gravitational attractions between the water and the crust cause the level to vary in different parts of the ocean. Physical climatic systems are also known to have caused short-term variations in many places through waves, currents, tides, changes in atmospheric pressure, and changes in ice, that is, water balance.

Sea level is purported to be rising worldwide and it is caused by both natural and human factors. Most research indicates that sea level is rising by approximately 6 millimeters a year [4]. In Ghana, some locations around Accra are projected to be inundated between the years 2035 and 2065 due to the sea level rise [5]. Another critical factor which is of major concern in recent years, also related to sea level rise, is the changing global climate. The outcomes of many scientific research works have indicated that the rate at which the present climate is changing may have varying impacts on both natural and human systems including the shoreline. On coastal regions, the greater risk, many experts warn, is that the changing climate is causing sea levels to rise with increasing rapidity and much of the waves and tides would be felt at the shoreline.

In Ghana, different scenarios for the estimation of current and forecasted sea level rise in the Gulf of Guinea are being developed. Trends on Ghana obtained using nationally observed climate data for the period of 1960 to 2000, coupled with regional climate models together with IPCC scenarios, revealed the following:

(1) The estimated temperature will continue to rise by on average about $0.6^{\circ} \mathrm{C}, 2^{\circ} \mathrm{C}$, and $3.9^{\circ} \mathrm{C}$ by 2020,2050 , and 2080, respectively.

(2) Rainfall is predicted to decrease on average by $2.8 \%$, $10.9 \%$, and $18.6 \%$ by 2020,2050 , and 2080 , respectively, in all agroecological zones except the rainforest zone, where rainfall may increase.

(3) A projected sea level rise (SLR) of $1 \mathrm{~m}$ by 2100 could see the loss of over $1000 \mathrm{~km}^{2}$ of land, with 132,000 people likely to be affected. The east coast is particularly vulnerable to flooding and shoreline recession [6].

Another critical factor that cannot be overstated is the increasing anthropogenic activities. Coastal population growth in many of the world's deltas, barrier islands, and estuaries has led to widespread conversion of natural coastal landscapes to agriculture, aquaculture, silviculture, and industrial and residential land uses [7]. It has been estimated that $23 \%$ of the world's population lives both within $100 \mathrm{~km}$ distance of the coast and $<100 \mathrm{~m}$ above sea level, and population densities in coastal regions are about three times higher than the global average [8]. The attractiveness of the coast has resulted in disproportionately rapid expansion of economic activities, settlements, urban centers, and tourist resorts. Migration of people to coastal regions is common in both developed and developing nations. Sixty percent of the world's 39 metropolises with a population of over 5 million are located within $100 \mathrm{~km}$ of the coast, including 12 of the world's 16 cities with populations greater than 10 million. Rapid urbanization has many consequences; for example, enlargement of natural coastal inlets and dredging of waterways for navigation, port facilities, and pipelines exacerbate saltwater intrusion into surface and groundwater, all of which affects the coastline. The direct impacts of human activities on the coastal zone have been more significant over the past century than impacts that can be directly attributed to observed climate change $[9,10]$. The major direct impacts include drainage of coastal wetlands, deforestation and reclamation, and discharge of sewage, fertilizers, and contaminants into coastal waters. Extractive activities include sand mining and hydrocarbon production, harvests of fisheries and other living resources, introduction of invasive species, and construction of seawalls and other structures. Engineering structures, such as damming, channelization, and diversions of coastal waterways, harden the coast, change circulation patterns, and alter freshwater, sediment, and nutrient delivery. Natural systems are often directly or indirectly altered, even by soft engineering solutions, such as beach nourishment and foredune construction [11, 12]. The impact of human activities on the shorelines of Ghana has been well studied and they include sand mining, urbanization and economic activities, fishing, and oil and gold mining $[1,2,5]$.

This study analyzes the role of erosion and accretion in shoreline change between the geographic regions from Cape Coast in the central region to Sekondi in the western region of Ghana. The area covers a stretch of land from EkonCape Coast, through Komenda to Ngyiresia near Sekondi fishing harbour. The area lies within longitudes $1^{\circ} 200^{\prime} \mathrm{W}$ and $1^{\circ} 400^{\prime} \mathrm{W}$ and latitudes $5^{\circ} 00^{\prime} \mathrm{N}$ and $5^{\circ} 100^{\prime} \mathrm{N}$. Figure 1 is the map of the study area. The vulnerability of the study area to both erosion and accretion is primarily due to its zonal orientation and the fact that it is an open coast that enables swell waves to break obliquely to the shoreline, generating longshore currents that carry sediment alongshore [13]. It is also partly due to the rock type and structure. There are rocky areas while others have sandy shorelines which offer varying degrees of erosion and accretion.

The study sought to understand the spatial and temporal dynamics and the rate of erosion and/or accretion within the study area from 1972 to 2013. Three study sites were sampled for the study, that is, Ekon-Cape Coast, Komenda, and Sekondi, basically based on lithology (Figure 1).

\section{Method}

Both primary and secondary data were used for the study. The primary data were obtained from the field including on-site information, interviews, observation, and GPS mapping. Secondary data used include orthophoto (2005) and toposheets (1972) which were obtained from the Ghana Survey Department. 


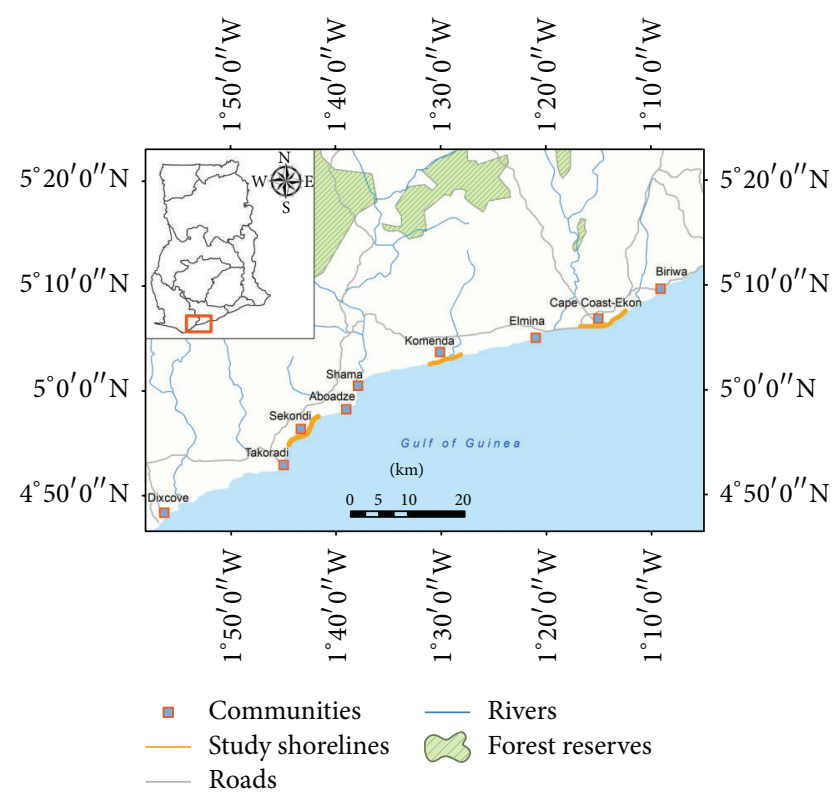

Figure 1: Coastal stretch from Cape Coast to Sekondi. Source: Cartography and GIS Laboratory of the University of Cape Coast, 2014.

Shoreline positions were generated from the three sources: toposheet (1972), orthophoto (2005), and field GPS mapping (2013). The 1972 toposheet for the study was made digital through a large format scanner and was scanned under a resolution of 300 pixels per inch (ppi). The high ppi was essential to maintain the resolution of the toposheet so as to enhance digitization. Digital version of the toposheet went through georeferencing based on the first-order polynomial (affine) with a root mean square error of 0.0002 . Orthophoto (2005) had a resolution of $0.5 \mathrm{~m}$ with positional and geometric corrections already undertaken by the Ghana Survey Department. Possible errors in shoreline position may relate to tidal fluctuation as the orthophoto was captured in the month of May (spring). This is the transitional period between low and high water marks. Unfortunately, there were no successive images to help in calculating its error. However, the possibility of errors was seen as uniform since the orthophotos were captured in the same month. Digitizing of both shorelines was performed under 1:2000 scale factor. In deriving the shoreline (2013), the researcher employed the Tremble Juno SD GPS device to traverse the shore of the study areas. Mapped shoreline was downloaded in shapefiles because the base coordinate of the GPS was set to the coordinate (Ghana Metre Grid). This was the same coordinate system as the other two data sources used in the study. This was done to cater for coordinate transformation errors which could have influence on the accuracy of the data. Most often positional uncertainties in shorelines are due to digitizing error, conversion error associated with toposheet, and tidal fluctuations. Uncertainty levels obtained were for the 1970 shoreline, \pm 4.2 for 2005 and \pm 9.3 for 2013 shoreline. All the captured shorelines were merged into a single feature class in ARCGIS 10.1 personal geodatabase as the accepted format for Digital Shoreline Analysis Systems. Transects with $250 \mathrm{~m}$ interval and $300 \mathrm{~m}$ length were cast onshore and perpendicular to the shorelines. A 50-meter buffer line generated from the 1970 shoreline served as the baseline for casting transects. The length of the transects was made high enough to allow all three shorelines to be crossed. This is because the length has a greater implication for results. Transects which do not cross all shorelines often return empty values in End Point Rate Analysis and Linear Regression. End Point Rate (EPR) was calculated by dividing the distance of shoreline movement by the time elapsed between the oldest and the most recent shoreline. The formula is stated below:

$$
\begin{aligned}
& \text { Thus EPR } \\
& =\frac{\text { distance in meters }}{\text { Time between the oldest and most recent shoreline }} .
\end{aligned}
$$

The extent of change was interpreted with reference to the degree of erosion and/or accretion, that is, whether it is extreme/maximum erosion or moderate to minimum erosion or maximum to moderate accretion. Negative values indicate erosion while positive values indicate accretion. One advantage of this method is that it is easy to compute as one needs only two shoreline dates. The major disadvantage according to Crowell et al. [14] and Dolan et al. [15] is that where more data are available the additional information is ignored. The method described above had been used by the USGS in the study of the coast along Commonwealth Massachusetts to determine changes along the shoreline [16]. A major disadvantage of EPR is the neglect of other shorelines by considering the earliest and the latest ones. Thus, the third shoreline (2005) was not incorporated in the statistical analysis of shoreline change.

\section{Results and Discussions}

The results of the analysis are presented in three spatial segments between 1972 and 2013. These are the shoreline position and change of the Cape Coast area, the shoreline positions and change for Komenda area, and the shoreline position and change of Sekondi area below.

3.1. Shoreline Positions and Change for Cape Coast. In this section, the study presents the results of the analysis of the shoreline position and how the shoreline has changed between 1972 and 2013. Figures 2 and 3 show the shoreline positions and change for Ekon-Cape Coast study site between 1972 and 2013. Interestingly, the shoreline has been unstable between the study periods. Figure 2 shows how the shoreline positions have been fluctuating between 1972, 2005, and 2013. The 1972 shoreline position served as the base year for the study. By 2005, the shoreline had retreated inland.

On the other hand, the shoreline position for 2013 shows a major retreat of the sea. The retreat and advancement of the sea are more pronounced in the central portions and less in the eastern and western portions of the study area. The rate of advancement and retreatment of the sea was almost the same along the shoreline. The extreme west and the extreme east of the shoreline could not be significantly eroded due to the 


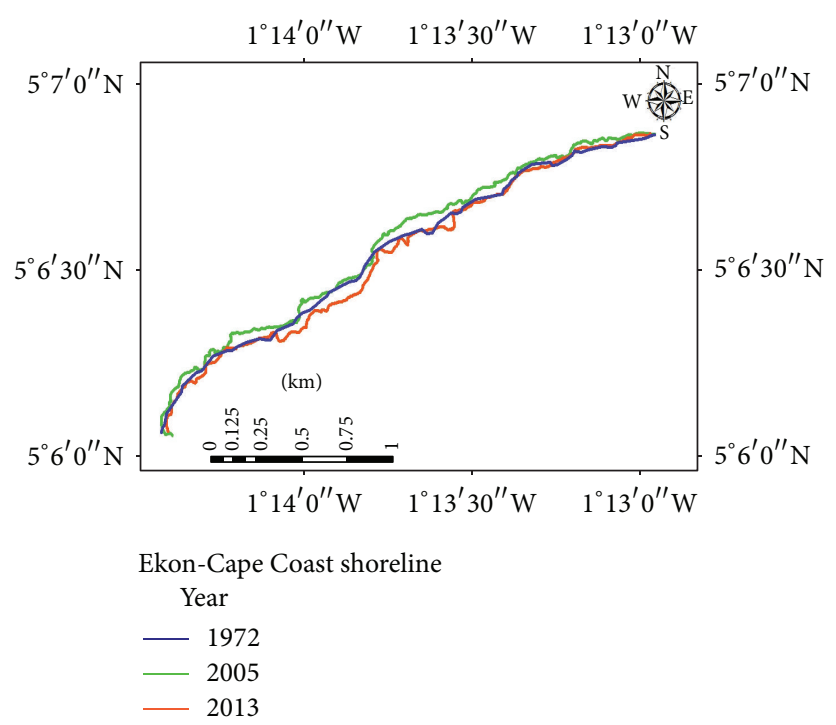

Figure 2: Shoreline positions for Cape Coast (1972, 2005, and 2013). Source: field survey and laboratory analysis, 2014.

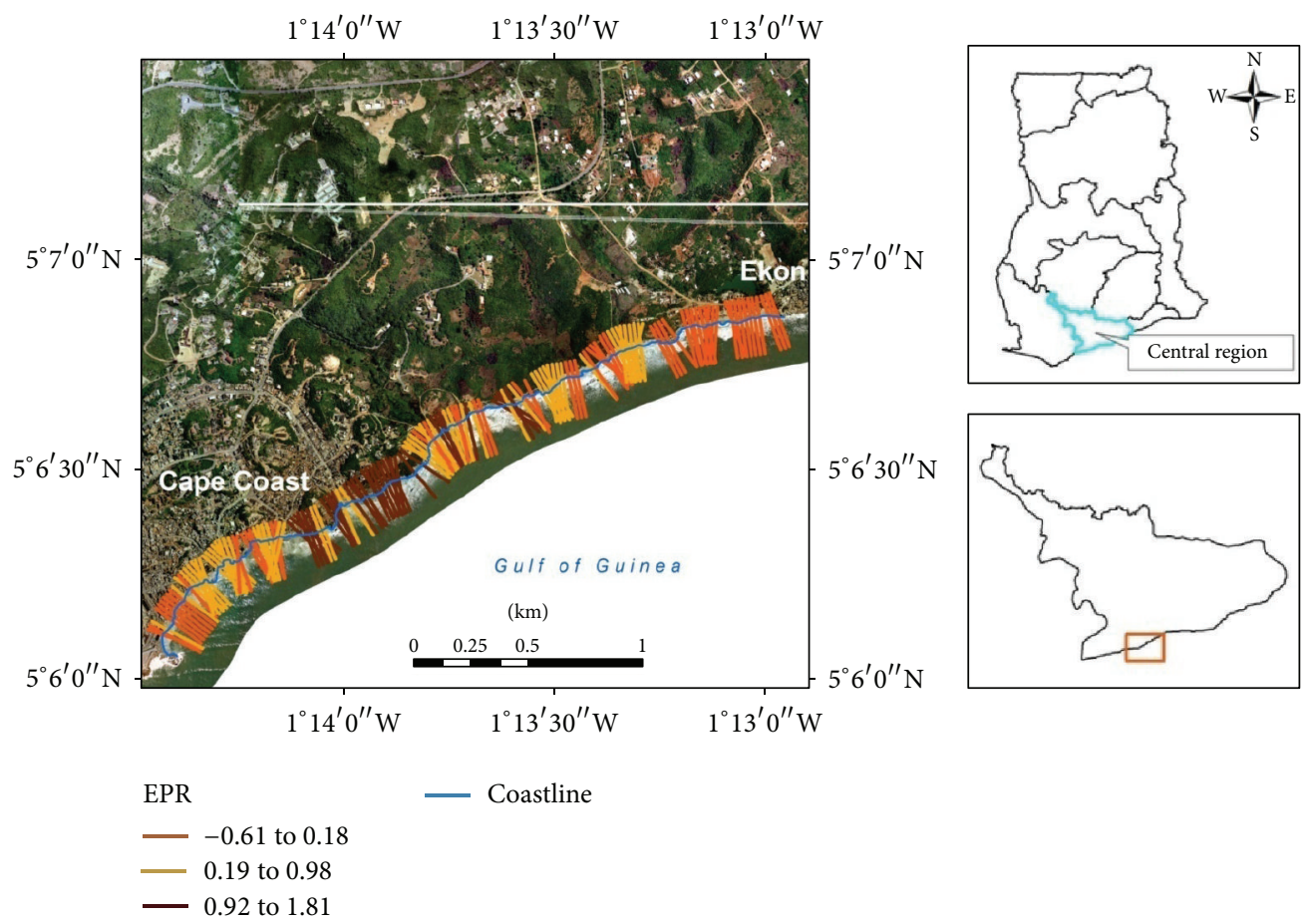

Figure 3: Shoreline change for Cape Coast (1972, 2005, and 2013). Source: field survey and laboratory analysis, 2014. Note that the negative values indicate maximum erosion while positive values indicate minimum erosion and, hence, accretion. The blue line indicates 2013 shoreline, while the transects depict rates of erosion and accretion.

rocky nature of the coast. The middle portion is very sandy; hence, the sea was able to erode deep into the land by 2005 and at the same time it was also able to significantly retreat by 2013. Figure 3 shows the changes along the coastline based on the level of erosion (advancement) and accretion (retreat). The occurrence of accretion or erosion is generally attributed to the differences in resistance to erosion and deposition along the coast.
Figure 3 shows the extent of shoreline change around the coast of Ekon and Cape Coast due to differences in erosion and accretion. The rate of change is between minimum of -0.61 and maximum of $1.81 \mathrm{~m} / \mathrm{yr}$. The mean rate of erosion was $-0.33 \mathrm{~m}$ with a standard deviation of 0.58 . Figure 3 shows that, between Cape Coast and Ekon, erosion was stronger with the maximum distance around Ekon. In other words, from Figure 3, the eastern portion (Ekon area) of the coast 
was under serious erosion but erosion becomes moderate and reached minimum as one moves towards Cape Coast, which is the western end of the shoreline. Erosion again intensifies at the extreme west of the coast after Cape Coast towards the west end of the study area. Thus, erosion was at its maximum around Ekon; it reduces as one moves westwards towards Cape Coast and then increased after Cape Coast towards the extreme west. It can therefore be said that, between Cape Coast and Ekon, there was less erosion.

The main reason that could be assigned for intense erosion around Ekon was that most of the coast was observed to be sandy and open. As a result, the waves have easy access to the beach without much obstruction. In areas westward from Ekon, there was minimum erosion and hence more accretion due to the rocky and resistant nature of the coast. The highest accretion rate was recorded around the rocky beach since the rocks served as a barrier. Notwithstanding, there was serious human interference in sections of the rocky coast which caused erosion. There was stone and gravel quarrying (sand and stone mining) at the beach west of Ekon behind the regional office at Cape Coast. These activities threaten the coastline since they make the coast more susceptible to erosion.

The study sought the opinion of local residents, against the fact that they have lived in the area for such a long time and as such their observations and opinions are important in validation of the satellite data analysis. Interviews conducted also confirmed that there has been serious erosion around the Ekon beach. The residents confirmed that, about five years ago, there was a beach resort with summer huts built at the beach. Unfortunately, the resort had to be abandoned due to the fact that the whole beach was inundated and the summer huts were destroyed by the sea. When one visits the area, there were visible signs of the abandoned development projects. It was found out that since then the sea had been retreating due to increased accretion.

3.2. Shoreline Positions and Change for Komenda. Another segment of the study area analyzed and presented in this paper is the Komenda section of the coastline. The ensuing paragraphs discuss the rate of erosion and accretion in relation to shoreline change for Komenda as shown in Figure 4.

From Figure 4, the general observation is that the shoreline of Komenda area did not experience much change as compared to that of Cape Coast and Ekon. From the baseline that is 1972, it could be seen that the sea had been retreating rather than advancing. The fluctuation is not very significant. The eastern portion of the coast is sandy while the western part is rocky. The rocks had always acted as barrier to erosion; hence, the eastern portion did not suffer from erosion. All in all, it can be said that the difference between and among the positions of the three shorelines was not very different. Figure 5 shows the rate of change in the shoreline around Komenda.

The shoreline change was computed for 154 transects with 300-meter distance. The highest long-term erosion change was -1.44 compared to low of $-0.28 \mathrm{~m} / \mathrm{yr}$. The highest longterm accretion rate was $0.32 \mathrm{~m} / \mathrm{yr}$ with a lowest of 0.02 . The mean of EPR was $-0.53 \mathrm{~m}$ with a standard deviation of 0.28 .

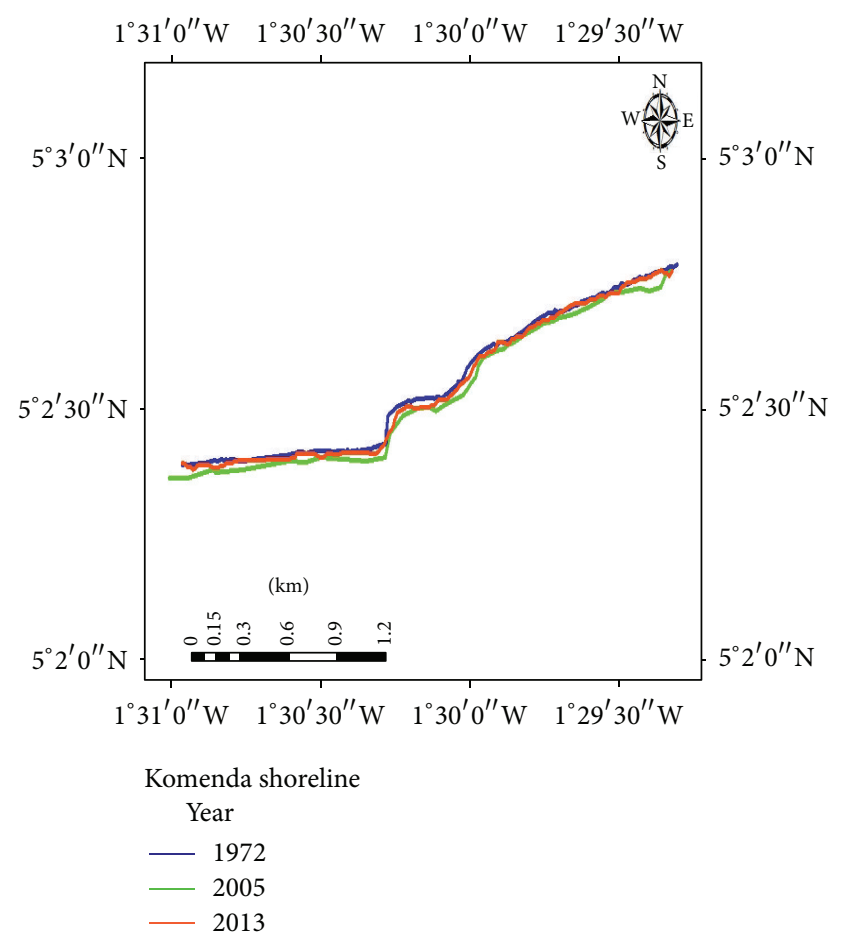

FIGURE 4: Shoreline positions for Komenda (1972, 2005, and 2013). Source: field survey and laboratory analysis, 2014.

The main contributing factor to this high rate of erosion was anthropogenic factors. This section of the beach is the most accessible by the inhabitants of Komenda. It also serves as recreational grounds for sporting activities and relaxation. Easy accessibility has also encouraged the activities of sand and stone mining in these parts for construction purposes.

3.3. Shoreline Positions and Change for Sekondi. Figures 6 and 7 also give detailed information on the extent of erosion and accretion through shoreline change analysis for Sekondi.

From the baseline, it could be seen that, between 1972 and 2005 , the sea retreated from the original position but began to advance towards the land again. The advancement through erosion was not sustained to catch up with the original position of the shoreline in 1972. In the extreme east, there was a vast difference between 1972 and 2005 but there was more deposition than erosion between 2005 and 2013. There is not much difference between the shoreline positions in the extreme west.

The coastline of Sekondi was measured at 97 transects along approximately $300 \mathrm{~m}$. The maximum erosion rate was -0.82 to minimum of $-0.35 \mathrm{~m}$ on the eastern side of the coast. Main shoreline rate of change was -0.24 with a standard deviation of 0.22 (Table 1). Erosion was moderate with the highest accretion occurring in the area around Ngyiresia beach with accretion rate between 0.01 and $0.34 \mathrm{~m} / \mathrm{yr}$. The extreme west was also accreting. It is thus realized that, on the average, the coastline of Sekondi has been accreting rather than eroding though there is physical evidence of serious erosion several years ago. This was also discovered during the community 


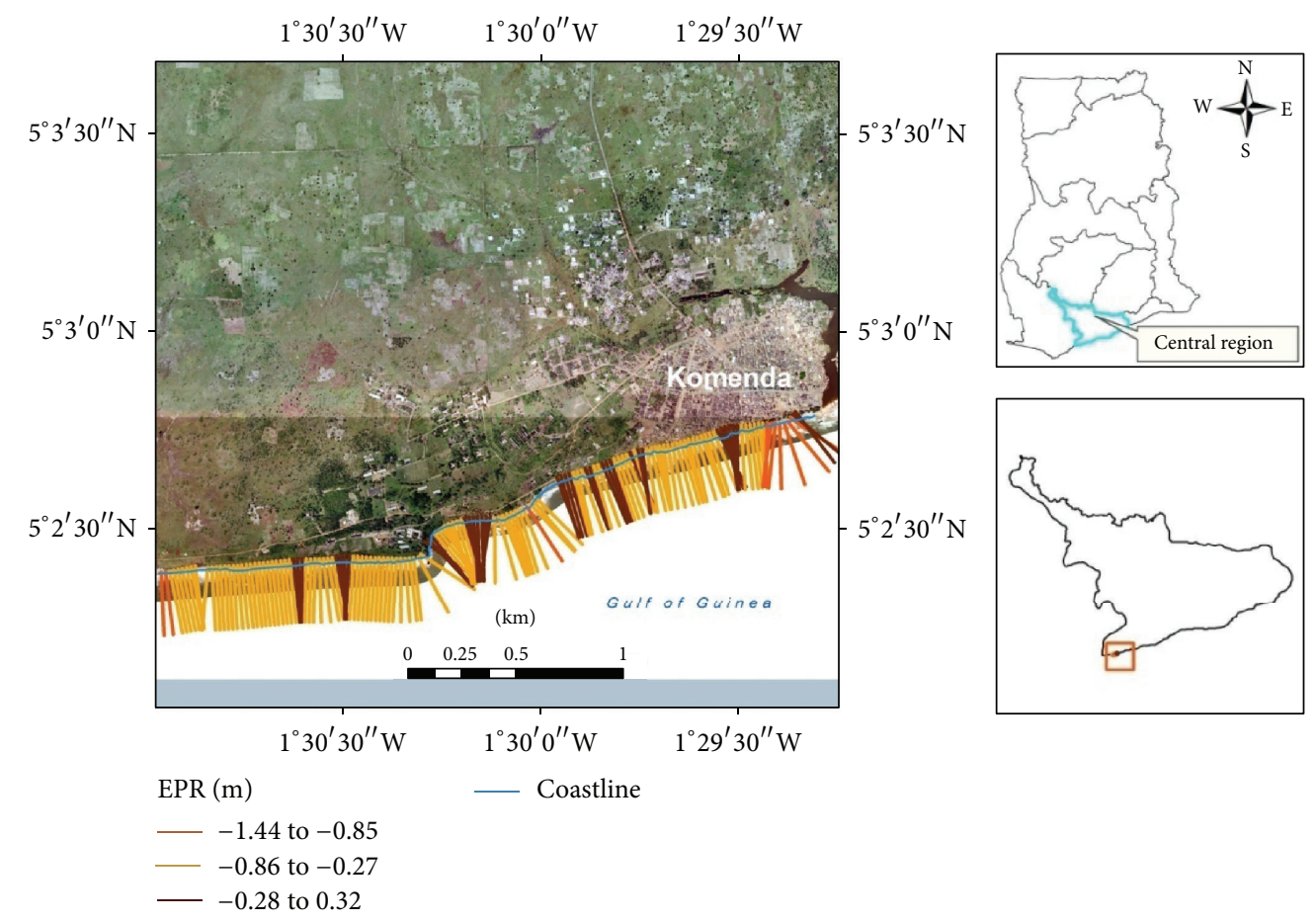

FIGURE 5: Shoreline change for Komenda (1972, 2005, and 2013). Source: field survey and laboratory analysis, 2014.

TABLE 1: Shoreline rate of change for the study areas.

\begin{tabular}{lcccc}
\hline Area & $\begin{array}{c}\text { Minimum } \\
\text { EPR }\end{array}$ & $\begin{array}{c}\text { Mean } \\
\text { EPR }\end{array}$ & $\begin{array}{c}\text { Maximum } \\
\text { EPR }\end{array}$ & $\begin{array}{c}\text { Std. } \\
\text { deviation }\end{array}$ \\
\hline Ekon-Cape Coast & -0.6 & -0.33 & 1.81 & 0.58 \\
Komenda & -1.44 & -0.5 & 0.32 & 0.28 \\
Sekondi & -0.82 & -0.24 & 0.34 & 0.22 \\
\hline
\end{tabular}

Source: field survey and laboratory analysis, 2014.

interaction. This necessitated the erecting of sea defenses such as groynes through the use of granites. This has contributed significantly to reduction in the advancement of the sea. The question this study posed was as follows: could the intensification of erosion around Sekondi-Takoradi be attributed to the construction of the Takoradi and Sekondi harbours? To some extent, it could be said that the existence of these harbours may have contributed to the high rate or erosion that extended inland some years ago until sea defenses were erected along the coast. In like manner, as in the case of the Tema Harbour which is believed to have contributed to the intense erosion around Keta which is located east of the harbour, the high rate of erosion around Sekondi and Nkontompo is attributed to the Takoradi Harbour, as these communities are also located on the eastern side of the harbor.

In general, erosion activities were much profound in Komenda with a mean rate of $-0.5 \mathrm{~m}$ per year. Sekondi enjoyed the lowest EPR of -0.24 . Disparity in mean rate of erosion can be attributed to geology type and human activities. Geology type underneath Komenda is of sandstones and grits which are much erodible than the more resistant granitoid geology in Cape Coast and Sekondi areas. Sections of the Cape Coast-Ekon shorelines were much characterized by rock outcrops which are most often accessible. This has resulted in the deposition weathered materials which are coarse rather than fine sand in Komenda area. This also partly accounts for the high rate of sand and stone mining in the area.

3.4. Interactions with the Local Communities. Aside field measurements and GIS analysis, which are stated in the methodology, community interaction was also carried out to get historical narrations on shoreline change in the study area. The opinions of local residents are considered vital firsthand information for validating the findings from the results of data analysis. The ensuing paragraphs thus discuss the results from the data analysis in relation to the opinions and observations of the local inhabitants.

Throughout the fieldwork, the research team observed that the shoreline of the area under study, like other areas, has been undergoing some changes. This may be attributed to the incidence of alternating and constant erosion and accretion. As a result, the shorelines kept fluctuating. In all the three study sites sampled, the local residents stated that erosion usually becomes very strong between May and August each year. The inhabitants could not give any specific explanation as to why this happens in that period but they believed that it is a normal behaviour of the sea, which they have observed over several years. However, climate data shows that the period May-August is the peak of raining season of the area. This study thus concludes that, due to the rain season during this period, that is, May to August, large volumes of water are supplied from inland rivers and streams that augment 


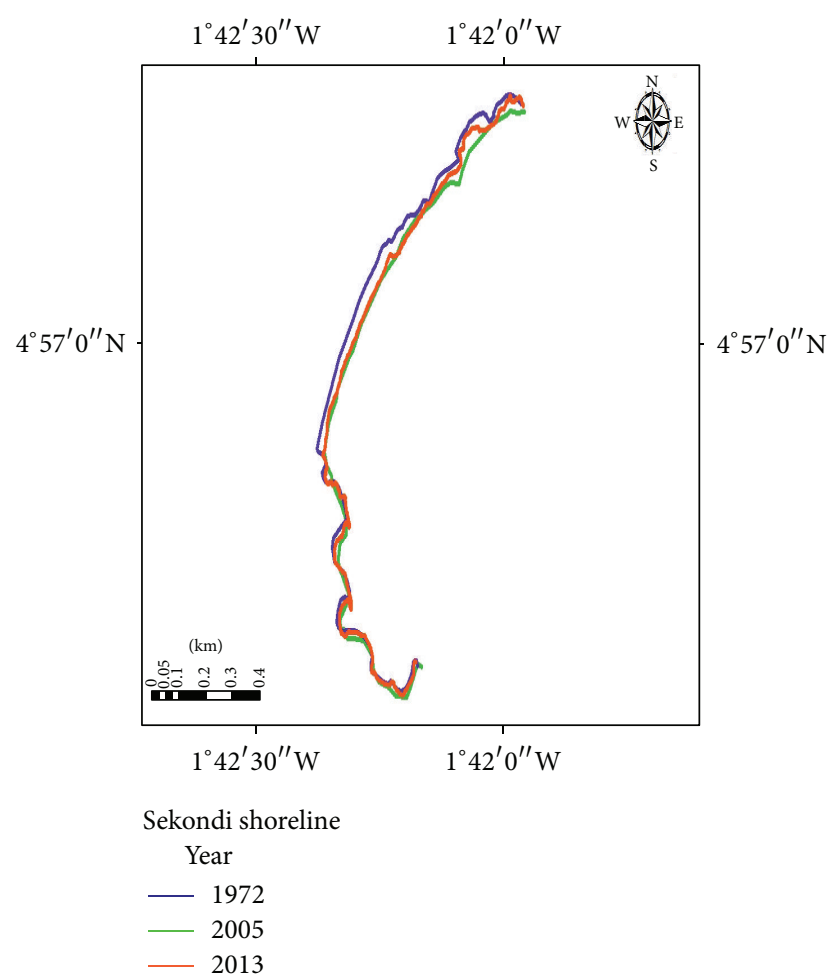

Figure 6: Shoreline positions for Sekondi (1972, 2005, and 2013). Source: field survey and laboratory analysis, 2014.

the sea's ability to move sand through strong waves, winds, and currents thus contributing to changes along the shorelines. This is in line with the assertion of Gibeaut et al. [17], when they argued that "the changes along a shoreline are caused by changes in the forces that move the sand, namely, wind, waves, and currents and by the supply of sand while short-term and long-term relative sea level changes also control shoreline movements." Waves, for instance, change the coastline morphology and form the distinctive landforms.

The physical shoreline change is also influenced by coastal engineering structures and other human activities. In all the three study sites, it was observed and also confirmed through the community interactions that there had been a retreat of the sea. This is because the beach had been raised due to hitherto erosion and subsequent accumulation of beach materials. At Sekondi, the observed retreat was between 20 and 30 meters from the shoreline. Previously, the sea was found close to residential areas; it later flooded the beach and now has retreated for a distance of about 25 meters. Between the Sekondi fishing harbour and Nkontompo, the story is different. There is evidence of coastal inundation and strong wave erosion. At Komenda, there is also evidence of raised beach due to hitherto strong waves and subsequent accumulation of sediments. According to the local inhabitants, for about three years now, the sea has never gone beyond a certain level though occasionally erosion becomes so serious that local mythology says it happens when gods are angry with the people.

At Cape Coast-Ekon, there is also evidence of advancing sea. There has been massive accumulation of sediments along the coast leading to upliftment of the beach. It can therefore be said that there had previously been serious erosion which was followed by continuous accumulation of beach materials, hence the development of raised beaches. Evidence of the advancing sea along the study area is the upliftment of the coastline due to massive accumulation of beach materials higher up the beach. The distance between the cliff face as well as dwelling houses and the present lower water mark is very short. During the community interactions, it was revealed that the advancement of the sea towards the beach has been very rapid between the last two and five years. This is because the beach which used to be recreational grounds for tourist and holiday makers has been lost to the sea. Summer huts and other structures which were erected at the beach are no more. The beach was full of coconut trees but now you can count not more than ten coconut trees around Ekon.

Around Sekondi and Komenda, it came out that though the sea has advanced, there seems to be a retreat of the sea. At Gold Hill Beach around Komenda, for instance, presently, it is very difficult for sea erosion to seriously attack the entire cliff due to an increasing distance between the land and the sea. This shows that, previously, the sea was very close to the cliffs, hence the total collapse of the cliff face. Moreover, there is also the presence of artificial barriers, some of which are now farther from the sea. There is also evidence of structures which were previously under serious wave attack but are now found at some distances away from wave action point. All these point to the fact that the sea is retreating between Komenda and Sekondi more than Cape Coast-Ekon. All in all, it can be concluded that the changes in the shoreline under study have been influenced among other things by human and natural processes. Jonah et al. [18] have previously observed erosion in the area when they observed short-term formation of scarps and periodic exposure and covering of underlying beach rocks, partly contributing to changes along the coastline of Elmina through Cape Coast to Moree.

\section{Conclusion and Policy Implications}

The study analyzed the role of accretion and erosion in shoreline changes along the coast between Cape Coast and Sekondi in the central and western regions of Ghana. The study concludes that accretion and erosion are both active and have contributed to the fluctuations of the shorelines in many locations along the study area, particularly the three study sites, though at different times, types, and rates. It is also found that the two processes of shoreline change (erosion and/or accretion) are still active and this calls for continuously monitoring the shoreline in order to keep abreast of the changes that are occurring from time to time and from location to location. The study opines that coastal dynamics such as erosion, accretion, and shoreline movements may not be strictly studied within the natural setting without considering the human dimension. It is therefore very imperative that laboratory analysis be verified with community interaction or local observations. Communities' history, mythology, and observations help in the understanding of the various dimensions of the issues and also in attributions. The views of the inhabitants are very important because they are 


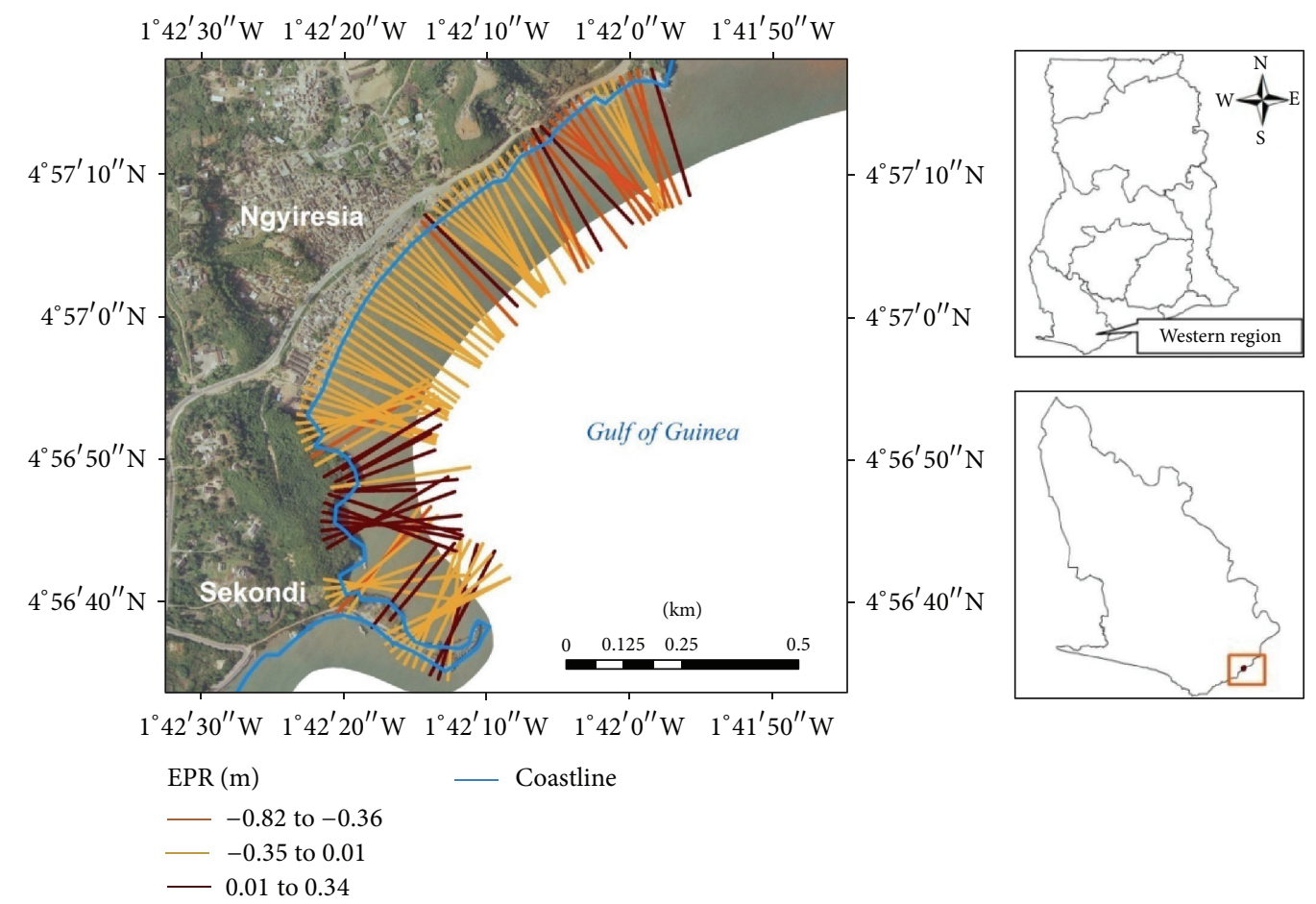

Figure 7: Shoreline change for Sekondi (1972, 2005, and 2013). Source: field survey and laboratory analysis, 2014.

the immediate victims of the actions of the sea. As a result, any plan towards the utilization of coastal resources as well as restoration of the beach needs to take into consideration both the natural and the cultural settings of the coastal zone. Thus, community participation in both national and local initiatives at tackling the problems associated with sea erosion, accretion, and net shoreline movements is highly recommended.

\section{Competing Interests}

The authors declare that they have no competing interests.

\section{References}

[1] J. F. Ekow, Coastal Erosion in Ghana: A Case of the Elmina-Cape Coast-Moree Area, 2015.

[2] K. A. Addo, "Monitoring sea level rise-induced hazards along the coast of Accra in Ghana," Natural Hazards, vol. 78, no. 2, pp. 1293-1307, 2015.

[3] D. Waugh, Geography: An Integrated Approach, Thomas Nelson and Sons, Edinburgh, UK, 1995.

[4] R. A. Warrick and J. Oerlemans, "Sea level rise," in Climate Change: IPCC Scientific Assessment, J. T. Houghto, G. H. Jerkins, and J. J. Ephraumus, Eds., Cambridge University Press, Cambridge, UK, 1990.

[5] K. A. Addo, "Managing shoreline change under increasing sealevel rise in Ghana," Coastal Management, vol. 42, no. 6, pp. 555567, 2014.
[6] National Adaptation Strategy. Ghana, National Adaptation Plan Presented at the Expert Meeting on National Adaptation Plans, Don Chan Place, Vientiane, Laos, 2011.

[7] I. Valiela, Global Coastal Change, Blackwell, Oxford, UK, 2006.

[8] C. Small and R. J. Nicholls, "A global analysis of human settlement in coastal zones," Journal of Coastal Research, vol. 19, no. 3, pp. 584-599, 2003.

[9] D. Scavia, J. C. Field, D. F. Boesch et al., "Climate change impacts on U.S. coastal and marine ecosystems," Estuaries, vol. 25, no. 2, pp. 149-164, 2002.

[10] H. K. Lotze, H. S. Lenihan, B. J. Bourque et al., "Depletion, degradation, and recovery potential of estuaries and coastal seas," Science, vol. 312, no. 5781, pp. 1806-1809, 2006.

[11] K. F. Nordstrom, Beaches and Dunes of Developed Coasts, Cambridge University Press, Cambridge, Uk, 2000.

[12] L. Hamm and M. J. F. Stive, Coastal Engineering, Shore Nourishment in Europe, 2002.

[13] A. K. Armah, "Coastal erosion in Ghana: causes, patterns, research needs and possible solutions," in Proceedings of the 7th Symposium on Coastal and Ocean Management, pp. 2463-2473, ASCE, July 1991.

[14] M. Crowell, B. C. Douglas, and S. P. Leatherman, "On forecasting future U.S. Shoreline positions: a test of algorithms," Journal of Coastal Research, vol. 13, no. 4, pp. 1245-1255, 1997.

[15] R. Dolan, S. Trossbach, and M. Buckley, "New shoreline erosion data for the Mid-Atlantic Coast," Journal of Coastal Research, vol. 6, no. 2, pp. 471-477, 1990.

[16] USGS, "Historical shoreline changes and associated coastal land loss along the US Gulf of Mexico. National assessment of shoreline change part 1," USGS Open File Report 2004-1043, 2004 . 
[17] J. C. Gibeaut, T. Hepner, R. Waldinger et al., "Changes in gulf shoreline position, Mustang and North Padre Islands, Texas," A report of the Texas Coastal Coordination Council pursuant to National Oceanic and Administration, 2001.

[18] F. E. Jonah, E. A. Mensah, R. E. Edziyie, N. W. Agbo, and D. Adjei-Boateng, "Coastal erosion in Ghana: causes, policies, and management," Coastal Management, vol. 44, no. 2, pp. 116-130, 2016. 


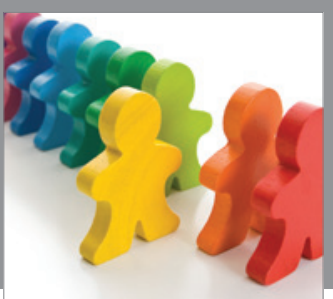

Autism

Research and Treatment
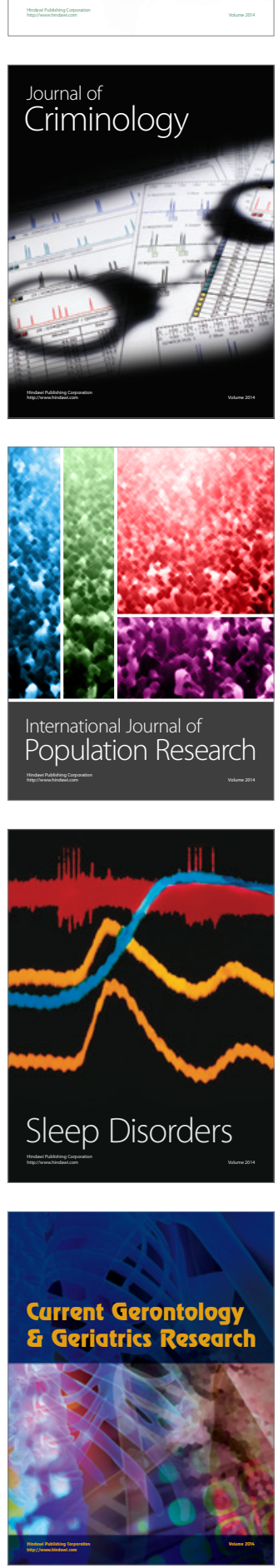

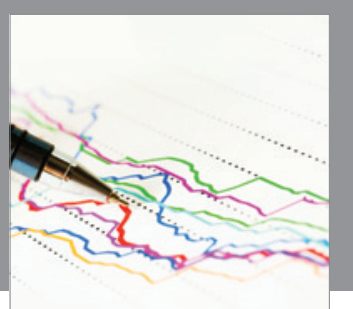

Economics

Research International
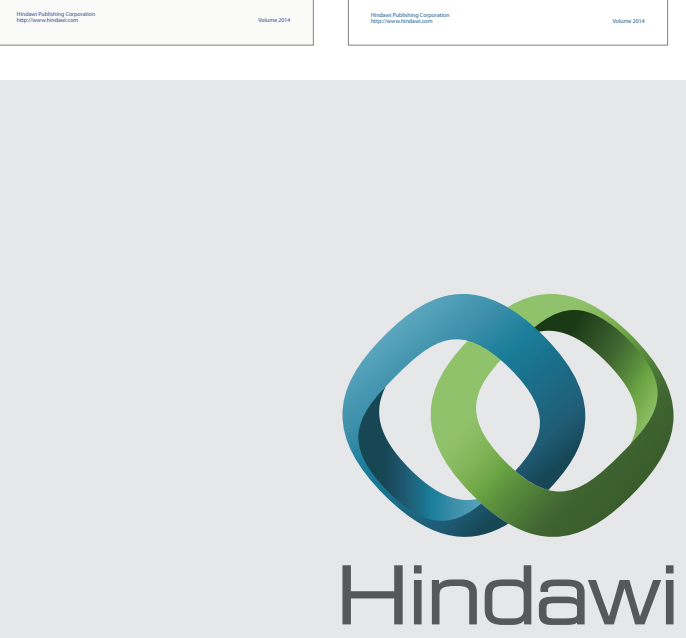

Submit your manuscripts at

http://www.hindawi.com
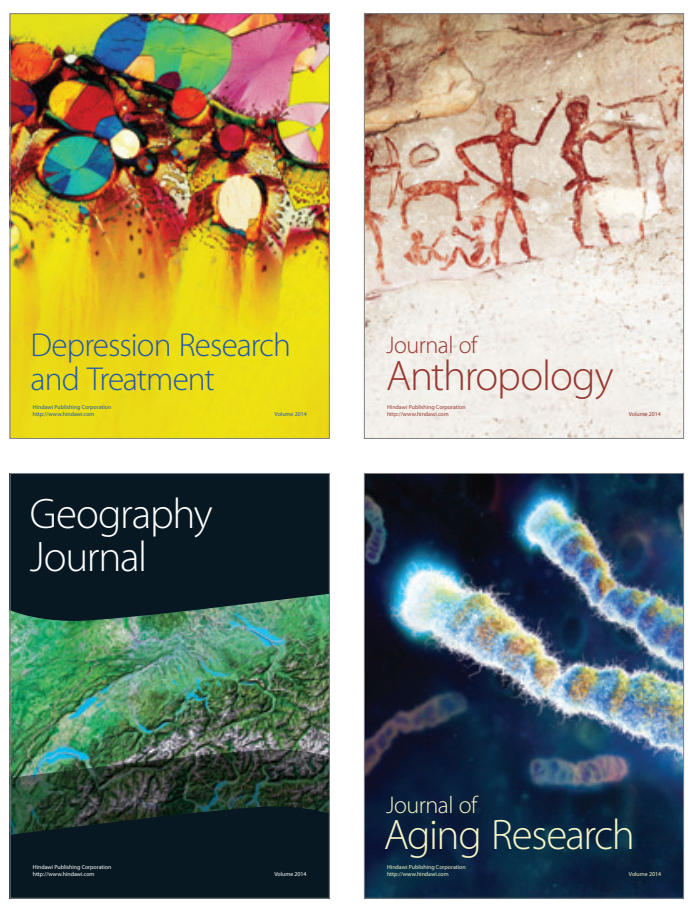
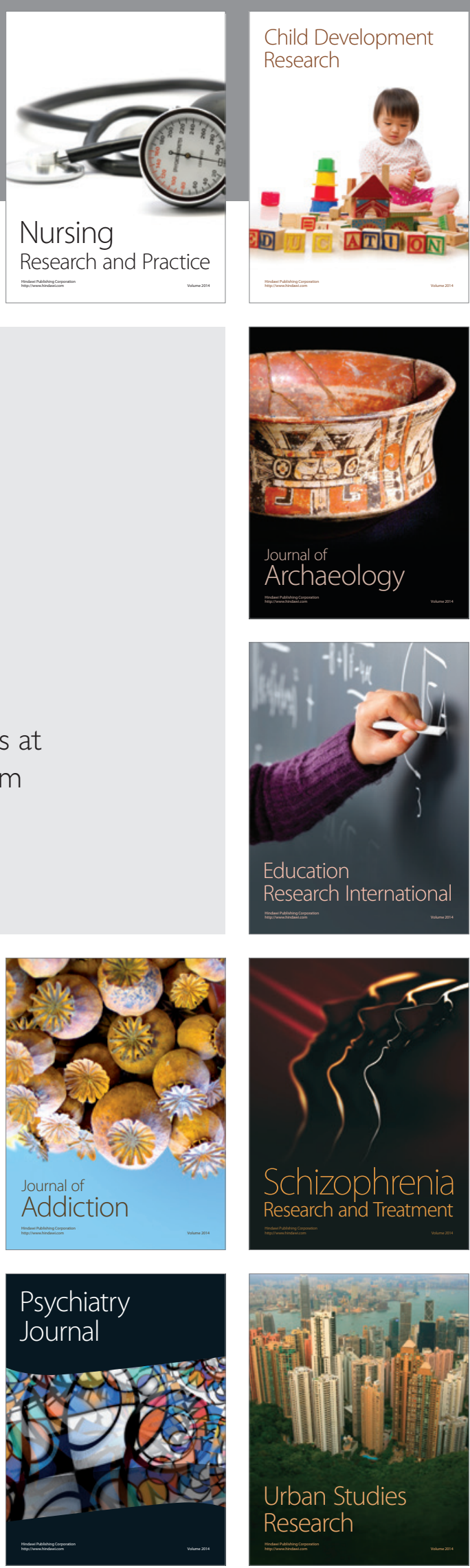